\title{
Strategy of Ethnic Identity Negotiations of Javanese Migrants Adolescents in Family Interaction
}

Komunitas: International Journal of Indonesian Society and Culture 9(2) (2017): 237-245

DOI:10.15294/komunitas.v9i2.8071

(C) 2017 Semarang State University, Indonesia p-ISSN 2086 - 5465 | e-ISSN 2460-7320 http://journal.unnes.ac.id/nju/index.php/komunitas

UNNES JOURNALS

\author{
Nina Yudha Aryantia', Deddy Mulyanab, Haryo S. Martodirdjo \\ 1Jurusan IImu Komunikasi, FISIP, Universitas Lampung, Indonesia \\ ${ }^{2}$ FIKOM, Universitas Padjadjaran, Jatinagor-Sumedang, Jawa Barat, Indonesia \\ ${ }^{3}$ Jurusan Sosiologi Antropologi, Universitas Padjadjaran, Jatinagor- Sumedang, Jawa Barat, Indonesia
}

Received: March 2016; Accepted: August 2016; Published: September 2017

\begin{abstract}
This article seeks to discuss the strategies of negotiation of Javanese ethnic identity in families among Javanese migrants in Lampung. The study found that there are three ways where the adolescents of Javanese migrants negotiate their ethnic identity. First, the adolescent states Javanese ethnic identity as a positive identity safely at family interaction. Second,they state Javanese ethnic identity as a single identity negatively in an unsafe situation. This happens when the adolescent avoid another ethnic identity that directed to them based on labeling in the family. Third, the adolescent choose one of two ethnic identities in a positive way. It's referring to parent's ethnic identity differences. Further, they use Javanese and non Javanese language at their family interaction as a basis for selecting ethnic identity.
\end{abstract}

\section{Keywords}

ethnic identity; family interaction; adolescents

\section{INTRODUCTION}

The family has an important role for its members in developing their identity. In particular, adolescent as a family member are in a number of positions within the nuclear or extended family. In nuclear family, adolescent have role as brothers or other siblings, and as children in relation to parents. While the extended family, adolescent are in a position as cousins, nephews and grandchildren. On the variety of positions and roles, the adolescent must be able to be in multiple roles within the family (Bacigalupe \& Cámara 2012; Hill \& Torres 2010). As the first environment for adoles- cents, family have an important position to support adolescents to form, develop and negotiate their identity, include their ethnic identity (Aldred 2013; Bodenhausen 2010; Ergun \& Erdemir 2010). At this family, adolescent was learning roles according to their status in the social interaction. Position as a child, dominate the adolescent status in the family. Adolescent dependency on the family put them in a weak bargaining posi-

\footnotetext{
Corresponding author

Jurusan IImu Komunikasi, Gedung C, FISIP, Univer-

sitas Lampung, Jl. Sumantri Brojonegoro 1, Bandar

Lampung, Indonesia,

Email

nina.unila@gmail.com; deddymulyana96@yahoo. com; haryo2016@unpad.ac.id
} 
tion within family interaction. Adolescents as children are in a process of adaptation, not only adaptation in various situations in the family; but they also proceed in the development of psychological stage and age. Adolescent's adaptation within family are a learning process that it's simultaneously with the adolescent process to search for their identity. In this condition, adolescent be required to have communication skills, so their interaction within family can support the process to find their identity positively (Clark 2011; Kinginger 2013; McLeish \& Oxoby 2011; McLean et al. 2010; Von Korff \& Grotevant 2011).

With minimal competence, the adolescent negotiate their ethnic identity. From this interaction, the adolescent get experiences to be a reference in the next process of interaction. The adolescent's experience gained from the process of cultural socialization and agreement of parents to choose which culture that developed and referenced in the family. This shows that the ethnic identity of parents affect the dynamics of cultural socialization in the family. Aryanti (2015, p.251) states that the inter-ethnic marriages (amalgamation) affect cultural socialization in the family. In amalgamation, parent ethnicity (husband and wife) and its dominance affect the transfer of material culture to their children. This is different from the family who is married with the same ethnic (marriage to the same ethnic). Moreover, Aryanti (2015, p.253) states that the adolescents formation of ethnic identity within families at Lampung Province are based on six things, i.e. (1) the history of migration family to Lampung province, (2) culture that adopted and referred at family, (3) the development of identity within family, (4) parenting, family time and the type of father's job, (5) the language that use within family, and (6) the situation that support and hinder the revelation of ethnic identity.

The knowledge and experience of the interaction of adolescent within the family serve as the basis for them to negotiate their ethnic identity. Based on the observations, the adolescent required more to represent and negotiate their ethnic identity within families, than other interactions (e.g., at school, peers or community). It's cause the adolescent ethnic identity in the family are: (1) reflects the dominant culture, parenting and communication patterns are referred and developed in the family; If adolescents behave badly in society (or others interaction outside family), it reflects the poor parenting and transfer of cultural values in the family, (2) it indicated how many cultures are socialized and accepted by adolescent; and (3) it also reflects the identity of family. Finally, this identity will be family identity in society.

Beside the importance of interaction and identity of adolescents in the family; psychologically, they adolescent have a main duty to seek their self-identity include the ethnic identity. In the process of searching for identity, adolescents negotiate their ethnic identity. So, the negotiation of the adolescent ethnic identity within family becomes the important thing.

In concept, Lewicki et al, (1999, p.141145) states that: (1) communication is a core of the negotiations; and (2) the fundamental questions in research communication and negotiation is how communication is done during the negotiations? Furthermore, the negotiation process is not limited to reciprocal information exchange, but also focused on how they share information and meaning to one another that affect to the negotiation process. More, Tutzauer (in Lewicki 1999, p. 8-9, 146) states that communication as a basic of negotiations focused on three aspects, are (1) the communication is a dynamic process and its changes all the time; (2) the process of communication is interactive that involve their bargaining position to influence others; (3) the negotiation is influence by internal and external factors.

Through negotiations, a person is in a situation of mutual dependence interaction with each other, so they adjust to, not only on the interaction situation and the context, but also conform to their interaction purposes. Then, the motive and timing factors also influence the dynamics of the interaction.

Thomson, Peterson and Ray (in Le- 
wicki 1999, p.267) states that there are some social context in the negotiations, are (1) they are who involve in the interaction; (2) social knowledge and purposes that owned and desirable; (3) norms, social rules, and the relationships types that were develop and built during the negotiation process; (4) the process communication with verbal and non verbal language, how each one interacts at informal rules that referred and developed in communication.

In line with the understanding of the negotiations, Negotiating Identity Theory that used to discuss this research have three assumptions: (1) the linkages and interdependencies of individuals and communities to support for each other; (2) the society that consists of a dynamic process of interaction; and (3) cognition, emotion and behavior are sometimes modified and changed by individuals. According to this theory, identity is defined as a combination of a sense of selfidentification at the interaction of human, cultural, social and personal as a manifestation of the experience that acquired and established by individuals. Then, Wiseman (1993, p.74) states that negotiation of identity are relate to some aspect, are:

"(1) individual in cultures hold multiple images concerning the sense of self; (2) cultural variability influences the locus of self - identification; (3) a individual's selfidentification involve both structure and process - while the structure of one's sense of self-identification confers existential security, the change process of self-identification promotes existential vulnerability; (4) the motivations of human communication are to reinforce existential security and diffuse existential vulnerability via identity boundary regulation; (5) identity boundary regulation process are expressed through the dialectical management of inclusion and differentiation; (6) the dialectical inclusion and differentiation rests on an optimal balance of self, others, group membership; (7) the effective management of inclusion-differentiation dialectic influences our sense of coherence level and our global self esteem level; (8) a coherent sense of self conception enhances cognitive, affective and behavior resourcefulness and these resource contribute to both knowledge and predispositions to effective identity negotiation process."

The above explanation states that in general there is a strong linkage between the negotiation, communication and context. In essence, the negotiation process is a communication process, which involves a lot of people, oriented on both sides and the current situation of the negotiations or communications.

Associated with the development of adolescent social self, Rogers (in Santoso, 2010, p. 46-48) states that the meaning of self and interaction comes from the everchanging experience. This experience obtained from: (1) a new experience being observed, developed and arranged to add a reference to a person; (2) The experiences that do not fit will be allowed or denied by an individual; (3) a new experience as opposed to self-rejection or developed in accordance with the change. Further, this experience does not match the structure of the self.

Besides that, individuals also used their the experience as the basic of behavior, are: (1) behavior based on positive experiences tend to be reinforced and assimilated with previous experience; (2) negative experiences tend to be avoided if the interaction is considered to threaten the stability of the self. In some cases, negative experiences will be modified as a defense mechanism against threats; (3) the undeveloped experience would tend to raise self-exploration that led to inconsistent behavior; (4) the new experience will process as a positive or negative experience, or delayed the process in accordance with the ability of self.

Based on observations, researchers found that the phenomenon of negotiation of adolescent Javanese ethnic identity migrant's occurs at family in Lampung Province. In the negotiation process, the adolescent proceeds to develop positive and negative experiences by exploration and self-development. The development demand of the adolescent experience in the 
interaction depends on the response and interaction within family situation. Ideal demands of ethnic identity in the family also influenced the dynamics of the negotiation of Javanese migrant ethnic identity within families.

From the above description, the researchers state that this research problem, is how the negotiation strategy of ethnic identity of the adolescent Javanese migrants within family interactions at Lampung province. Then, this study aimed to get an explanation and analysis of the negotiation strategy of ethnic identity of the adolescent Javanese migrants within family interactions at Lampung province. In this study I argue that there are three ways where the adolescents of Javanese migrants negotiate their ethnic identity.

\section{Ethnic Identity in Family}

This research is phenomenology, which focuses on how adolescents awareness Javanese migrants in negotiating their ethnic identity within family interaction. The reason for choosing this based on the observation that the majority of adolescent need their ethnic identity in families. It deals with the identity of the family in society, so this identity is important not only for adolescent but also for the family.

Informants were selected purposively with the specification are: the adolescent are the second or third generation of migrants Java, one or both parent's is Javanese, adolescents and their families live in the Lampung Province. Moreover, the investigators defined three categories of families of adolescents are: (1) the Javanese family (husband and wife are Javanese); (2) The amalgamation family that husband is Javanese with the wife is non Javanese; (3) the amalgamation family that husband is not Javanese with Javanese wife. The research data was collected by participant observation that supported by in-depth interviews and documentation. Processing and data analysis was done by reduction, presentation and verification of data (Moleong 2005, p. 288). Then the validity of the data is done with perseverance observation, extra-time observation and triangulation (Birowo 2004, p. 5-8).

The results showed that adolescents have minimum of competence and ability in the negotiation of ethnic identity in families. In general, the adolescent want to be perceived as Java, even though they have one parent is non Java. This is because: (1) adolescents feel comfortable being Java; (2) there is a high degree of social acceptance in social interaction, as he admitted / behaves as Java; (3) there is a stereotype of ethnic non-Java so this stereotypes make them feel uncomfortable in social interactions, if he is not considered Java; (4) there is a stereotype in other ethnic groups within family. The stereotypes will appear when they do not behave according to the Javanese culture. This gave rise to their labeling in the family. Adolescents tend to get frustrate when they get this labeling. It's caused the adolescent have a lack of knowledge to Javanese culture causes they feel unsafe and uncomfortable in the interaction so they avoid the ethnic identity exposure as a Javanese, and adolescents negotiate himself as a child in the family.

The facts show that in the negotiation process, the adolescents as individuals who are active and have the awareness to give feedback in interaction within the family. But the family's power positioned the adolescent as children who have a weak bargaining position in the family interaction. In this situation, adolescents adapted to the previous experience. If they ever been in a situation similar interactions in previous interactions; they makes their experiences as reference in response. For example, if the situation is almost the same from previous interactions, they received a positive response, and then the adolescent can develop a positive response. And otherwise, if from previous interactions, the adolescent get a negative response, they tend to not refer or they seek another alternative response. In this situation, the negotiation of ethnic identity teens occurred.

In the process at dynamic family interaction, the adolescents are individuals who are active and have the awareness to give feedback to the messages that it receives. 
This awareness is on how they are displaying behavior as an expression of the interpretation of the interaction experienced. In general, the negotiations of the adolescent of Javanese ethnic identity in families characterized by using the Java language at certain level, other ethnic languages were developed in the family and the Indonesian national language.

The results showed that adolescents are demanded to show the ethnic identity based on the cultural identity that family referred. The poor knowledge and experience of adolescents to the Javanese culture set them in a difficult position. Demands for present the Javanese cultural make the adolescent tend to reconstruct the Javanese culture that referred as the basis for negotiations in accordance with their competence.

In an effort teenager to be considered as part of the ethnic identity of the family, they have a strategy to state or negotiate their ethnic identity, are: (1) the adolescent negotiated single ethnic identity as Javanese identity positively in a safe atmosphere within family. (2) The adolescent negotiated Javanese ethnic identity as a single identity in a positive in safe atmosphere and negative at unsafe atmosphere. (3) The adolescent choose one of the two ethnic identities of parents positively.

\section{Adolescents negotiated single ethnic identity as an ethnic Javanese posi- tively.}

In the interaction of adolescent within family, they tend to represent and negotiate their ethnic identity in a positive way. This condition has been linked to ethnicity parents and dominance of Javanese culture in the family. It's occurred on the three types of families below:

a. Adolescents with Javanese parents

b. Adolescents with Javanese father and non Javanese mother,

c. Adolescents with non Javanese father and Javanese mothers. Further they live the mother's extended family, so the Javanese culture became dominant in the family

The results showed that in general,
The Javanese adolescent negotiated their ethnic identity by by reconstructing the Javanese culture that is referred in the family. It is associated with knowledge, understanding and acceptance of adolescents to Javanese culture in the family. In general, they know the culture of Java on a limited basis from a culture that applied to everyday life, for example the use of the Javanese language at certain level in the family.

Furthermore, the adolescent only know the Javanese language in certain level, but not for the other Javanese culture. Results of interviews with adolescent parents indicate that traditional Javanese ritual in the family is not the responsibility of the child, but on who is the eldest in the family. The practice of Javanese culture also depends on the knowledge and understanding of the family elders of the Javanese culture. This condition is a basic for the adolescent to feel comfortable when they negotiating their ethnic identity based on the Javanese culture that they understand. The Javanese cultures that apply in family tend to be flexible toward Javanese cultural boundaries, and tend to apply the common ethic. The adolescent general habitude when they negotiated their ethnic identity, they mostly use the lowest level of Javanese language (Bahasa Jawa Ngoko) straightforwardly to anyone who meet, include the parents that older than them.

In principle, the Bahasa Jawa Ngoko used in interaction with the lower social interaction partners. It's happens in Lampung Province, because minority of the adolescent parents did not able to use the higher level of Javanese language (Bahasa Jawa Krama or Krama Inggil). The higher level of Javanese language dominated by grandparent or they who were born and have the childhood on the island of Java

Within the context of family interaction, the adolescent tend to be not developing ethnic identity negatively. Its cause the adolescent did not get a labeling to their speech and behave that it did not appropriate to Javanese culture at their interaction. In general, the positive negotiation of Javanese ethnic identity occurs at the adolescent of 
second or third generation.

\section{Javanese ethnic identity as a single identity}

In the family interaction, the adolescent of third Javanese generation tend to represent and negotiate their ethnic identity in negative ways. It's experienced by the adolescent who both their parents are Javanese and their grandparents live around them.

The results showed that in general, the adolescents negotiate ethnic identity in a negative ways. It's occurs when they are in uncomfortable and unsafe of family situation interactions. This usually happens when the adolescent do not speak or behave in accordance with Javanese culture. It is valued by parents or grandparents. In contrary, the adolescent of third generation develop and negotiate their Javanese ethnic identity when they are on the safe and comfort interaction situation.

The adolescent have a weak bargaining position at family interaction. Thus, at the next interaction, if they are in insecure and uncomforting situation interaction, they tend to be quiet, passive and stay in the interaction until the situation well. In this situation, the adolescent lean their identity as children or grandchildren in the family. In certain of this situation interaction, the adolescent frustrate when their interaction respond did not proper with the situation and they get an interaction labeling. This label came from the Javanese cultural of ethnocentrism and the stereotype to others cultural. Further, Rochana \& Nina Y (2012, p.612) state that the Javanese marriage (husbandwife are Javanese) tend to have a higher degree of ethnocentrism and stereotype than the marriage of different ethnicity. More, the dynamics of ethnocentrism and stereotypes formation within family also determine by the multicultural pattern of settlement. The other hand, this studies show that the ethnocentrism use as a basic to determine the standard of Javanese cultural at family. Then, the stereotype use as a basic to determine labeling on the speech, attitude and behavior of family members who are not in accordance with Javanese culture referenced and developed in the family.

Different with the adolescent who develop their ethnic identity positively; the adolescent who develop their ethnic identity in negative ways tend to be having a Javanese language better then them who develop their ethnic identity in a positive way. There were a positive thing when the adolescent negotiate their Javanese ethnic identity negatively; they tend to be more polite in their interaction. But, in common, the adolescent do not understand the Javanese cultural like the others age.

They use the Ngoko Javanese language when they interact with peers or those who are younger. Whereas they interact with older people in the family, they will use the Karma Javanese language with a limited vocabulary, such as inggih (yes), mboten (no) or they use the national language (Indonesian) with a nonverbal attitude is not straightforward and polite. The Javanese language using of family older make the adolescent can be able to use the higher level of Javanese language. Then, the Karma Inggil Javanese Language used well by their grandparents. Whether as the parent ability of Javanese language is slightly better than adolescent

Beside language, the Javanese cultural practice at this family better than others. Grandparents who were born and get a childhood at Java Island have better Javanese cultural experience than those who were born in Lampung. This suggests that the place of birth affects the ability of Javanese language of Javanese migrant. Furthermore, knowledge and experiences grandparents of Java cultural is use to set the standard of speech, attitudes and behavior as Javanese in the family. Standard as Javanese within this family are higher than the adolescents who develop a family of ethnic identity in a positive way.

\section{Dual ethnic identity}

The adolescent tend to represent and negotiate the dual ethnic identity at family whose: (1) the adolescent who have a Javanese father with non Javanese mother, (2) the adolescent who have non Javanese father with Javanese mother. 
The results showed that the exits of the dominant culture in the family (or both parents are equally dominant culture) based on the condition that the Javanese father has more social power than the mother. It is caused by several factors: (1) the concept of "guru laki" at Javanese culture places men (husbands) are more dominant in the family. (2) In some families with the husband's parents (grandparents of the adolescent) stayed together or nearby them. It's forced the Javanese culture development in the family.

On the other hand, mothers who is non Javanese has a major role in child care, so mothers have enough time to interact and express their cultural (non-Javanese) at children (the adolescent). These conditions have also strengthened the non-Javanese culture in the family.

At this family, there two cultures have a balance power to adopt. Javanese wife (adolescent mothers) also apply the Guru Laki Concept, so she will regard husband as a family leader and she had to accept and adapt to the non Javanese culture of husband. This condition makes the wife (the adolescent mothers) can receive non Javanese culture in the family and she will be implemented the Javanese cultural based on her acceptance and understanding of the culture of Java. Finally, the amalgamation family has two cultures that developed in the family. Cultural dominance is determined by the power of bargaining position of parent (husbandwife) in the family.

The 'war of two cultures powers' (Java and non Java) in the family demanding the adolescent as member or children to know and understand it, even though it was only in the use of language (as one of a cultural component) in the family. The adolescent's type has better language skills than others. Furthermore, Aryanti (2013, p. 238) states that the language use in family interaction

1 Guru laki concept is Javanese cultural view that positioned man (or husband) as a (family) leader so man has a higher position than women. This concept adopt not only in family but also in Javanese society. In its development, now, this concept tend to be change because there a development concept of gender equality. is influenced by: (1) parenting and communication patterns within the family, (2) a dominant culture that developed and adopted in the family, (3) the level of closeness adolescent to the father and or mother, and (4) the availability time to interact in the family.

The results showed that there are three negotiation strategies of ethnic identity of adolescent Javanese migrants. In general, according to the Identity Negotiation Theory assumptions stated that the negotiations of Javanese ethnic identity of Javanese migrants within the family, are:

1. The adolescent have an attachment, dependency and support one another in the family and society. It is show that in the negotiations ethnic identities of adolescent in families, they have an attachment to parents and culture material is socialized in a family. Next, the adolescent dependency to the family occurs when the send and accept of material culture are socialized. Then, the support of parents to the adolescent address to form the ideal of ethnic identity in the family. This support is provided in two forms, are (1) the positive ethnic identity development of adolescent Javanese migrant support by an not strict to apply the Javanese culture. They adopt the common ethics and norms at family; (2) the negative ethnic identity development of adolescent Javanese migrant was done by labeling, so by labeling, the adolescent will behave according to the standard criteria of Javanese culture that applied in the family.

2. The process of family interaction is dynamic. It's shown that the family interaction develop and adapt at various situation of interaction. In specific ways, the adolescent discover their social role by this process.

3. The adolescent use their past experiences to give response at negotiation process in family in various situations. Based on the theory and the research result, the adolescent negotiation of Javanese ethnic identity develops in family dyna- 
mics interactions, whether it is in a nuclear or extended family. Further, this negotiation is directed to: (1) develop of adolescent selfidentity, (2) increase adolescent communication skills, (3) increase the adaptive power of adolescents at various environments; so it reveals that the family as the first environment for individuals (adolescent) has an important roles in the development of adolescent social identities, as part of the Java community in Lampung Province.

This research showed that the dynamic of negotiation of adolescent Javanese migrant determined by several factors, are: (1) the culture that developed and referenced in the family; (2) the daily language that is used in the family. The use of the Java language in the family is not related to the generation level and the dominant culture in the family, but the use of language in the family related to its use in the habit of daily interactions as part of the socialization process in the family culture. Further classes of Java language that use in interaction affect the attitudes and behavior of adolescents in interaction. (3) Situation interactions that affect adolescents comfort in the interaction. This is related to the presence or absence of labeling in the interaction in the family. In the interaction of adolescent in the family, they consciously willed Javanese ethnic identity. With the knowledge and experience minimal culture, youth culture references tend to be reconstructed in accordance with the level of understanding of the culture of Java.

\section{CONCLUSION}

The results showed that the dynamics of adolescent negotiation of Javanese ethnic identity migrant is determined by several factors, i.e.: (1) culture that developed and referenced within family; (2) the language that is used in the family. The use of the Java language in the family is not related to the level generation and the dominant culture in the family, but the use of language related to the habit of daily interactions as part of the socialization process in the family culture. Further, the level of Javanese language that use affects the attitudes and behavior of adolescents in interaction. (3) The interactions situation affects the adolescent's safety and comfort in the interaction. This is related to existence of labeling in the interaction in the family.

The adolescent want to prefer to be Javanese in family interaction. With the poor of knowledge and experience culture, the adolescent tend to be reconstructed Javanese cultural accordance with the level of understanding of the culture of Java.

\section{REFERENCES}

Aldred, R., 2013. Incompetent or too competent? Negotiating everyday cycling identities in a motor dominated society. Mobilities, 8(2), pp.252-271.

Aryanti, N.Y., 2013. Bahasa Remaja Transmigran Jawa dan Negosiasi Identitas Etnik dalam Komunikasi Antarbudaya di Lampung. Prosiding Hasil Penelitian dan Pengabdian pada Masyarakat. Universitas Lampung, Bandar Lampung. Lemlit, Unila

Aryanti, N.Y., 2015. Javanese Cultural Socialization in Family and Ethnic Identity Formation of Javanese Adolescent Migrant at Lampung Province. Jurnal Komunitas, 7(2), pp.251-253

Aryanti, N.Y., 2015a. Kompetensi dan Komunikasi Keluarga dalam Sosialisasi Budaya Transmigran Jawa dalam Latar Budaya Majemuk di Lampung. Laporan Penelitian DIPA BLU Senior. Universtas Lampung, Bandar Lampung.

Bacigalupe, G., \& Cámara, M., 2012. Transnational families and social technologies: Reassessing immigration psychology. Journal of Ethnic and Migration Studies, 38(9), pp.1425-1438.

Birowo, A., 2004. Metode Penelitian Komunikasi. Gitanyali, Jogjakarta.

Bodenhausen, G.V., 2010. Diversity in the person, diversity in the group: Challenges of identity complexity for social perception and social interaction. European Journal of Social Psychology, 40(1), pp.1-16.

Clark, L.S., 2011. Parental mediation theory for the digital age. Communication theory, 21(4), pp.323-343.

Downey, G., Jaquelynne S.E., Celina M.C., 2005. Navigating The Future: Social Identity, Copying and Live Task. Russel Sage Foundation, New York.

Ergun, A., \& Erdemir, A., 2010. Negotiating insider and outsider identities in the field:"Insider" in a foreign land;"outsider" in one's own land. Field Methods, 22(1), pp.16-38.

Goffman, E., 1963. Stigma: Notes on The Management of Spoiled Identity. Pelican Books, New Jersey.

Hill, N.E., \& Torres, K., 2010. Negotiating the American dream: The paradox of aspirations and achievement among Latino students and engagement 
245 Nina Yudha Aryantia et al, Strategy of Ethnic Identity Negotiations of Javanese Migrants...

between their families and schools. Journal of Social Issues, 66(1), pp.95-112.

Kinginger, C., 2013. Identity and language learning in study abroad. Foreign Language Annals, 46(3), pp.339-358.

Lewicki, R.J., David M.S., John W.M., 1999. Negotiation. Mc. Graw Hill Inc, New York.

McLean, K.C., Breen, A.V., \& Fournier, M.A., 2010. Constructing the Self in Early, Middle, and Late Adolescent Boys: Narrative Identity, Individuation, and Well-Being. Journal of Research on Adolescence, 2o(1), pp.166-187.

McLeish, K.N., \& Oxoby, R.J., 2011. Social interactions and the salience of social identity. Journal of Economic Psychology, 32(1), pp.172-178.

Moleong. L.J., 2005. Metode Penelitian Kualitatif. Remaja Rosda Karya, Bandung.

Mulyana, D., Solatun. 2007. Metode Penelitian Kuali- tatif: Contoh-Contoh Penelitian Kualitatif dengan Pendekatan Praktis. Remaja Rosda Karya, Bandung.

Rochana, E., Nina Y.A., 2012. Etnosentrisme dan Stereotip dalam Dinamika Interaksi Antaretnik di Propinsi Lampung. Prosiding Hasil Penelitian dan Pengabdian pada Masyarakat. Universitas Lampung, Bandar LampungLemlit, Unila.

Santoso, S., 2010. Teori-Teori Psikologi Sosial. PT. Refika Aditama, Bandung.

Von Korff, L., \& Grotevant, H.D., 2011. Contact in adoption and adoptive identity formation: the mediating role of family conversation. Journal of Family Psychology, 25(3), p.393.

Wiseman, R.L., Jolone K., 1993. Intercultural Communication Competence. Sage Publication. Inc, California. 